$\bar{I} Q \bar{A} N$ : Vol: 01, Issue: 02, Jun 2019

\title{
ISLAMIC PERCEPTION OF FREEDOM OF EXPRESSION (AN EXPLORATION OF ISLAMIC THOUGHT)
}

\author{
Dr. Riaz Ahmad Saeed \\ Department of Islamic Studies, \\ National University of Modern Languages, \\ Islamabad, Pakistan.
}

\begin{abstract}
Islam considers freedom of expression, speech and thought as an imperative human right and liberty. Primary Islamic sources, as the Holy Quran, Hadith and Seerah of the beloved Prophet Muhammad $(S A W)$ and Islamic jurisprudence discuss its principles parameters and boundaries comprehensively. There are many verses of the Quran, Āhō dith of the Prophet Muhammad (SAW) and many terms of Islamic Figh, which guide us to describe the freedom of expression, its meanings, significance, principles and limits. Islamic scholars of different fields define the freedom of expression in different ways. It's also observed during exploration in Islamic and Western perspectives, there is no specific and agreed upon definition of freedom of expression. Some scholars try to define it according to their own interest and requirement, but they can't make an agreement on its definition. So, there is found a variety of definitions of freedom of expression in academic discourse. Different Islamic scholars mention different definitions due to its being a modern term. In this study efforts are made to elaborate Islamic concept of freedom of expression, thought and speech in modern context. It's concluded, the Islamic teachings give all kind of freedom and rights to human being but their limits and boundaries are different from Western thought.
\end{abstract}

Key words: Islam teachings, basic concept, freedom of expression and speech, exploration.

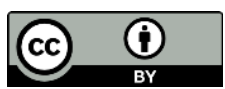




\section{Introduction:}

Freedom of expression has become one of the most noteworthy and hot issues in modern Islamic and Western thought. Due to its importance and controversy it has become one of the most common and much used contemporary sociopolitical terms. Both Islamic and Western thoughts consider it an essential basic human right throughout the history. There are many important documents regarding the freedom of expression, which can be put forward as evidences in legal, historical and socio-political perspective of Islam and the West. However, there is no specific and unanimous definition of the freedom of expression. Every school of thought is, at liberty to define it, according to its own perspective. Therefore, a renowned Islamic scholar Dr. Hāshim Kamālī assumes:

"Since freedom can apply to competing or even conflicting interests, it tends to defy the idea of a comprehensive definition of freedom. Which is precisely, why there is no clear definition of freedom of expression? There are of course, many attempts by writers, commentators to define freedom.

Yet they are all open to some level of uncertainty and doubt". ${ }^{1}$

This statement tells us that freedom of expression has a variety of definitions and there is no agreed upon definition in Islamic and Western context. Thus, there are numerous definitions of freedom of expression in Islamic and Western literature. At this point, the study will try to elaborate the meanings and concepts of the freedom of expression in the Islamic perspectives.

\section{Meaning of Freedom of Expression and Speech:}

Islmic literature including Arabic, Urdu and Persian present freedom of expression, speech and thought with different angles. According to some important dictionaries and lexicons the meaning of the word freedom of expression is as followed. The Arabic word Hurriyyah al-

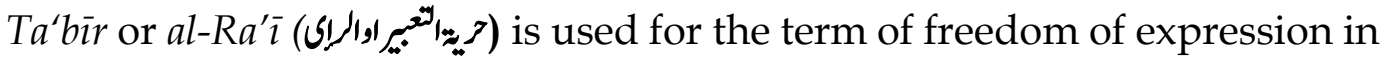
Islamic literature and Arabic dictionaries in the Islamic perspective.

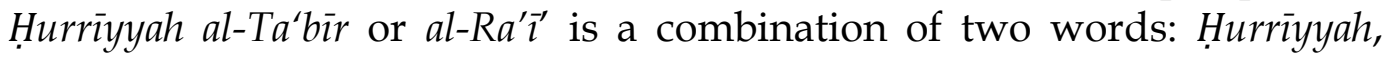
means freedom and liberty and $a l-T a^{\prime} b \bar{i} r$ or $a l-R a^{\prime} i^{\prime}$ means expression or

${ }^{1}$ Kamālī, Muhammad Hāshim, Freedom of Expression in Islam, (Kuala Lumpur: Berīta Press, 1994), p: 8 
$\bar{I} Q \bar{A} N$ : Vol: 01, Issue: 02, Jun 2019

speech. An important Arabic-English dictionary, Al-Mawrid Al-Wasit defines it alike, "Hurrìyah al-Ta'bir means freedom of speech, expression and freedom of opinion etc." ${ }^{1}$ There are a number of other words and terms that are used to describe the term freedom of expression in Islamic perspective. According to sheikh 'Abdul Jalīl Yahyā Farās, in Arabic freedom of expression means, "The Term Hurriyyah al-Ta'bir has many synonyms, like Hurriyyah al-Ta'bir, freedom of expression, Hurrìyyah al-Qawl (حيخ القول) freedom speech, Hurriyyah al-Bahath (حيخ البث) freedom of conversation and every term expresses almost the same meanings". ${ }^{2}$ In Arabic language and literature the above mentioned three terms have the same literal meanings and usage from Arabic to English language.

In the basic Islamic sources, the Quran and Hadith, the word Hurriyyāh is not used, but it is derived from the word Hurr or Taharrur, it means freedom or liberty from slavery and bondage. The Qurānic uses of the word are alike;

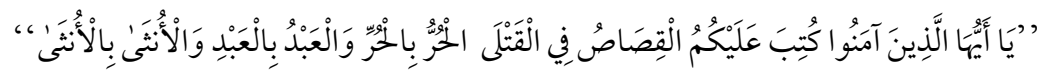

"O believers, the law of equality is prescribed to you in cases of murder: the free for the free, the slave for the slave, the woman for the woman"."

Furthermore, Hadrat 'Abdullah bin 'Abbās (RA) narrated in a Ḥadīth of the Prophet (SAW);

"The law of Qișaș (the capital punishment) was only prescribed for the children of Israel, but Diyyat (blood money) was not ordained for them as alternate, so Allah says: "O believers! The law of al-Qișāss prescribed for you in cases of murder: The free for the free, the slave for the slave and the female for female". ${ }^{4}$

In Urdu and Persian dictionaries the term Hurriyyah al-Ra' $\bar{\imath}$ is used for freedom of expression. According to an authentic Urdu Dictionary; "Hurrìyyah means Āzādī, Independence, independence from slavery and

\footnotetext{
${ }^{1}$ Mun̄̄r Ba'llbakkī and Rohī, Al-Mawrid Al-Wasīt, (Beirut: Dār al-‘Ilam li al-Malāyīn, 1981), p: 292

2،Abdul Jalīl Yahyā Farās, "Hurrīyyat al-Ta 'bīr kamā Qarrahā fi al-Quran”, Research Journal of al-Ambār Islamic University, Iraq1:3 (2009), pp:149-194

${ }^{3}$ Sūrah al-Baqarah: 178

${ }^{4}$ Bukhārī, Muhammad bin Ismā‘̄il, al-Ṣaḥ̄h al-Bukhārī, (Riyadh: Darussalam,1997), ḥ̣: 25
} 
$R a^{\prime} \bar{\imath}$ means consultation, thought and suggestion, etc." ${ }^{1}$ Therefore, it is perceived that in classical Arabic literature, dictionaries, encyclopedias as well in primary Islamic sources; Quran, Hadith and Fiqh the word 'Hurriyyah' is used for liberty as an opposite of slavery.

In Islamic perspective, in Arabic and Urdu languages the word al$R a^{\prime} i(ا ل ر ا ٕ)$ is used for expression or speech. There are many synonyms used for $a l-R a^{\prime} i$ (expression) for example al-Qawl (Speech), al-Bahath (discussion), $a l-F i k r$ etc. The word $a l-R a^{\prime} i$ is used for many meanings and objectives. The Classical Arabic dictionary Lisān al-Arab defines it in this way: "It means views and thinking about different issues and it is opposite of selfevident". ${ }^{2}$ While $Q \bar{a} m \bar{u} s$ al-Muhit states, "Views and thinking in different issues" ${ }^{3}$ According to Imām Ibn al-Qayyīm, al-Ra'î (expression) means that which is known by heart not by eyes". ${ }^{4}$ Imam Zarkashī says; "The exegetes (Mufassirin) used the word $a l-R a^{\prime} \imath$ as opposite of al-Naș (the text of the Quran and Hadith) to understand the Quran and the only opinion to understand the Quran is not a good approach". 5 In Arabic context, classical and modern literature the word Hurriyyah al-Ta'biror al-Ra' used to determine the term freedom of expression and speech, which means liberty to express, discuss, criticize and hold the ideas according to one's will and choice. Understanding of Freedom of Speech:

Keeping in view, in Islamic and Western perspectives, there is no specific and agreed upon definition of freedom of expression. Some scholars try to define it according to their own interest and requirement, but they can't make an agreement on its definition. So, there is found a variety of definitions of freedom of expression in academic discourse. Different Islamic scholars mention different definitions due to its being a modern term. Here, the research will try to present the definitions of some

\footnotetext{
${ }^{1}$ Mawlavī, Feroz al-Dīn, Ferìz al-Lughāt, (Lahore: Feroz Sons, 1994), pp: 551-671.

${ }^{2}$ Al-Afrīqī, Mukarram bin Manẓūr, Lisān al- 'Arab, (Beirut: Dār al-Fikr, 1986), 3:8-13

${ }^{3}$ Feroz Ābādī, Muhammad bin Y'aqūb, al- Qāmūs al-Mohịṭt, (Beirut: Dār al-Fikr, 1982), p: 1275

${ }^{4}$ Ibnal-Qayīm , Muhammad bin Abī Bakr, E'lām al-Mu'awiqīn, (Beirut: Dār al-Fikr,1976), $1: 60$

${ }^{5}$ Zarkashī, Badar ud Dīn, al-Burhān fi 'Ulūm al-Quran, (Beirut: Dār al-Fikr, 2001), 2:150
} 
$\bar{I} Q \bar{A} N$ : Vol: 01, Issue: 02, Jun 2019

particular Islamic scholars as well as from some selected dictionaries, encyclopedias and thesauruses.

According to Dr. Muhammad Suleiman al-Hagīl comments;

"Freedom of thought and expression means that a person can have complete freedom in saying the truth and advice in all worldly and spiritual matters for the purpose of serving the benefit of Ummah and protect the interest of both the individual and the community". ${ }^{1}$

Some other Muslim scholars ${ }^{2}$ also defines this term from their context. From the above definitions, it can be grasped that the scholars are not agree up on a single definition of the term freedom of the expression because of the involvement of one's likes and dislikes and different social and political perspectives. According to researcher's humble opinion, freedom itself is also a core issue in a contemporary intellectual Islamic and Western world that has to reach on one consensuses definition of the term. But I think this may not possible due to contradictions, clashes and differences between Islamic and Western views.

When we analyze the above definitions in an Islamic perspective, some points are common. Every scholar tries to define it in his special perspective. A notable majority of scholars are agreed upon on the theme that Islam grants freedom of expression, including the freedom of religion, thought and speech in every form of communication. Every scholar agreed on the point that Islam gives these freedoms with limits, terms and conditions on the ethical and legal basis. In my point of view; Dr. Kamālī's definition is more comprehensive. His definition illustrates the right of expression in any form of communication without any irrelevant restraint and bounds it with ethical and legal parameters. In one hand he bounds it

\footnotetext{
${ }^{1}$ Al-Hagīl, Selman 'Abdurrehmān, Human Rights in Islam and Refutation of the Misconceived Allegation Associated with these Rights, (Riyadh: Imam Muhammad bin Saud Islamic University, 1999), p: 61, Kamālī, Freedom of Expression in Islam, p: 9

${ }^{2}$ Wāfi, 'Abdul Wāhiid, Huqūq al-Insān fi al-Islam, (Cairo: Nahza Publishers, 1989), p: 80 ${ }^{2}$ Kamālī, Freedom of Expression in Islam, p: 9, Bhat, 'Alī Muhammad, "Freedom of Expressing from an Islamic Perspective”, Journal of Media and Communication Studies 6:5 (2014), p:72
} 
with legal and ethical limits and other hand opens it free until it damages the legal, social and religious norms and boundaries.

\section{Main Areas of Freedom of Expression:}

Various Studies and interdisciplinary researches show that freedom of expression has some major areas or types to understand and explain this term deeply. Even The primary sources of Islam; the Holy Quran, Nobel Āhādith and Sunnah of the kind Prophet (SAW) and Fiqh (Islamic jurisprudence) literature also discuss some important areas of it. Freedom to criticize is an important type of freedom of expression. In Islamic teachings, every Muslim is a part of Islamic state and society has the right to criticize the government, especially when a government crosses the limitations of the constitution or its authority, but this critique should be positive, as the basic principle of Islam is the cooperation in goodness and virtues. At more than one place of the Holy Quran Almighty Allah command the believers likewise;

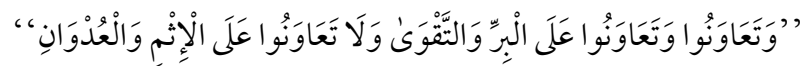

"And cooperate in righteousness and piety, but do not cooperate in sin and aggression. And fear Allah, indeed, Allah is severe in penalty". ${ }^{1}$

The beloved Prophet (SAW) considers the best people who are the best for others in ethics, morals, conduct and helping. Therefore, the Prophet SAW says in this regard, "The best among you, who are the best for other people". ${ }^{2}$ In some other judgments of the Prophet SAW commanding good and forbidding from evil is also considered a virtue. Thus, it is the best principle of Islam. The Muslim scholars also have their valuable views on this important subject and Islamic principle. Many Muslim scholars categorically describe this issue in many valuable ways. Among them one the most leading scholar of the $20^{\text {th }}$ century Mawlānā Mawdūdī interprets it in the Tafhim al - Quran;

"This obligation of inviting people to righteousness and forbidding them to adopt the paths of evil is incumbent on all true Muslims. If any government

${ }^{1}$ Sūrah al-Mā'idah : 2

${ }^{2}$ Qudhā̄i, Muhammad bin Salamā, Musnad Shahāb, (Beirut:Mu'assiah al-Risālah, 1986), h: 1234 
İQĀN: Vol: 01, Issue: 02, Jun 2019

deprives its citizens of this right, and prevents them from performing this duty, then it is in direct conflict with the injunction of God". ${ }^{1}$

An Islamic state cannot impose sanction on the freedom of expression until it crosses its limits against the established principles of freedom of expression. A partial moderate Pakistani Islamic scholar Dr. Muhammad Țāhirul-Qādirī argues, "In an Islamic society after the declaration of Almighty Allah as the only Sovereign authority, no one has authority to ban freedom of expression for the sake of like or dislike of a personality". ${ }^{2}$ Right to freedom of speech and expression can only be granted, limited and prohibited by Sharī'ah, not by any other legislation. Professor AM Bhat comments, "In Islamic legal discourse, freedom of speech and expression is controlled only where the failure to do so would result in harming the cause of truth and defaming other societies and their sentiments". ${ }^{3}$

In the following, the researcher will try to explain some important areas of freedom of expression to show how much variety of the freedom of speech is provided by Islam long before the world could know of the name and concept of free speech.

\section{Freedom of Thought:}

In Islamic perspective, freedom of thought is the most significant issue because many other obligations depend upon it. Islam gives the right to everybody in an Islamic state that one may describe his opinions according to his conscience and thought freely. Every citizen of the Islamic state and society has right to differ from others including government authorities on valid arguments. Thus, Almighty Allah ordains to the believers to obey Allah and his prophet in religious matters and in case of difference return it to the revealed scriptures;

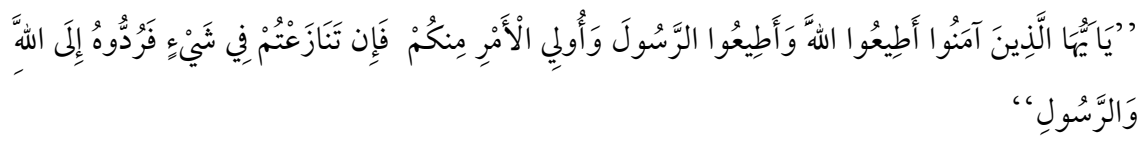

\footnotetext{
${ }^{1}$ Mawdūdī, Syed Abū al-A'lā, Tafhìm al-Quran, (Lahore: Tarjumān al-Quran Publishers, 2003), 2:215

${ }^{2}$ Qādirī, Muhammad Ṭāhir, Human Rights in Islam, (Lahore: Minhāj Publications, 2004), p: 309

${ }^{3}$ Bhat, Freedom of Expressing from an Islamic Perspective, p: 70
} 
"If ye differ in anything among yourselves, refer it to Allah and His Messenger, if ye do believe in Allah and the Last Day". ${ }^{1}$

Here one issue is most notable and mandatory that in Islamic freedom of thought and expression one may differ from others including higher government and intellectual authorities on any issue of sociopolitical, economic and religious, but one may not differ from the fundamental sources of the Sharī'ah (the texts Quran and Sunnah). Because these from almighty Allah, the supreme Lord of the universe. An Islamic scholar writes, "Obviously this Qurānic text anticipates the possibility of dispute arising between the ruler and his subjects, and it affirms that the duty of obedience does not overrule the rights of citizens to take issue with their leaders and the government". ${ }^{2}$ This valuable statement also assumes that any the citizen right of difference of view and freedom of speech cannot be violated in any case. When Almighty Allah grants them a right to differ them then how it can be violated or dismissed from any authority of this world. Therefore, Allah invites the people to think freely about their Creator and other sings of the universe frequently;

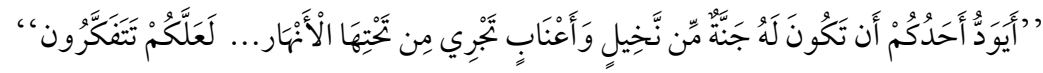

"Do any of you wish that he should have a garden with date-palms and vines and streams flowing underneath, and all kinds of fruit, while he is stricken with old age, Thus doth Allah make clear to you (His) Signs; that ye may consider". 3

This Nobel Qurānic verse invites people to investigate and explore the universe in a very comprehensive way. In this way, the Quran gives a person right to think out free opinion in his search for truth. Thus, Islam grants free thinking with much importance because it is a gate to reach the truth, which is the ultimate goal of Islam. Many Ahādīth of the Prophet SAW defines its importance. Once the Prophet SAW mentioned the importance of thinking and freedom of thought in these words, "Thinking of a moment is better than worship of a complete night". 4 Imām Abū Hāmid

\footnotetext{
${ }^{1}$ Sūrah al-Nisā': 59

${ }^{2}$ Kamālī, Freedom of Expression in Islam, p: 65

${ }^{3}$ Sūrah al-Baqarah, 2:266

${ }^{4}$ Muttaqī, 'Alāu'ddīn, 'Alī, Kanz al- 'Ummāl, (Beirut: Mu'assisah al-Risālah, 1979), ḥ: 5710
} 
İQĀN: Vol: 01, Issue: 02, Jun 2019

al-Ghazālī explains the significance and objective of thinking and thought;

"Thinking means to know two wisdoms as a result to get the third wisdom and the result of wisdom is only knowledge, and practices not anything else because practice is the result of knowledge and knowledge is the result of thinking. So, it is known that thinking is the foundation of every virtue". ${ }^{1}$

A leading Eastern scholar 'Allāmah Muhammad Iqbāl comments in this regard in his well-known Book;

"According to the Quran there is a greater objective work in the universe.

These are revolutions of nature that we compel to change ourselves into new phenomena. So when we try to think and explore knowledge, our lives become open, multidimensional and our wisdom becomes sharper". ${ }^{2}$

This statement is really a landmark judgment regarding Ijtehād in Muslim history. On the behalf of this most imperative principle, Iqbal presented a principle of movement in Islam which proved a mile stone for reconstruction of Islamic thought in Subcontinent specially and in general universally. After it a movement start about favor Ijtehād and anti-Taqlīd (Blind imitation) in all over the Muslim and this play a vital role to reconstruct Muslim thought according to modern needs and requirements.

Islam likes freedom of thought and expression because it is a source of exploring truth and to solve the human issues in circle of the Islamic Shari'ah. Here, it is also an important feature of the Islamic freedom of expression that it fixes the Islamic thought in some fundamental issues but makes it focused and flexible on some important aspects. It means Islamic thought and approach is at a time flexible and fixed one, dynamic and static. It depends up on situation and circumstances. For that unique purpose, Islam carries on the principle of Ijtihād to promote freedom of thought in Islamic sociopolitical perspective. Even in Islamic thought, for that purpose, if a scholar makes a mistake during Ijtihād unconsciously, then Islam gives him one reward. Here, the Prophet Muhammad SAW point outs some virtues and respect of a judge (Mujtahid) although he has wrong decision. It means here decision does not matter but means his struggle and intention

\footnotetext{
${ }^{1}$ Ghazālī, Abū Hāàmid, Ehyā al- 'ūlūm a-Dīn, (Beirut: Dar-ul-Fikr, 1980), 4:601

${ }^{2}$ Iqbāl, Muhammad, 'Allāmah, The Reconstruction of Religious Thought in Islam, (Lahore: Institute of Islamic Culture, 1986), p: 21
} 
towards making decision. Here, Almighty Allah grants him a virtue on the basis of intellectual hardworking and efforts.

"If a judge makes a ruling, striving to apply his reasoning (Ijtihäd) and he is correct, then he will have two rewards. If a judge makes a ruling, striving to apply his reasoning and he is mistaken, then he will have one reward". ${ }^{1}$

Therefore, due to the above discussion, it is clear that Freedom of thought has a vital place and key role in Islamic teachings. Freedom of thought has a very close relation to the freedom of speech because freedom of thought is the foundation brick of freedom of speech.

\section{Freedom of Religion:}

Freedom of religion is an important area of freedom of expression in an Islamic perspective which gives a person freedom of religion without any restriction. Allah, the Creator of the human being, describes this important right in the Quran; "There shall be no compulsion in the religion (alBaqarah: 256)". According to this verse there will not be any compulsion on a person to accept Islam. Islam grants him freedom of religious conscience and freedom at all. According to Syed Mawdūdī comments, "If somebody does not accept Islam, Muslims will have to recognize and respect his decision, and no moral, social or political pressure will be imposed on him to change his faith". ${ }^{2}$ According to the Quran, Muslims are forbidden to argue with non-Muslims in an aggressive and non-wise full way in religious matters. But they are advised to argue with them in wise full and decent manners. It is a most favorite subject of the Islamic teachings. The Holy Quran and Hadith of the Prophet describe it with full spirit and details. SAW. Even the classical Fiqh literature of Muslims is also describes its particulars. Here, Almighty Allah states in the Quran about principles of conversation and dialogue with People of the Book;

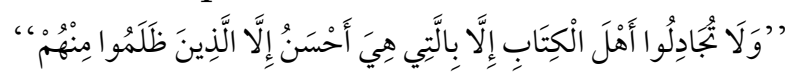

"And do not argue with the People of the Scripture except in a way that is best, except for those who commit injustice among them".

\footnotetext{
${ }^{1}$ Al-Qushayrī, Muslim bin Ḥajjāj, Șaḥ̄h Muslim, (Riyadh: Darussalam, 2007), ḥ: 1791

${ }^{2}$ Mawdūdī , Human Rights in Islam, p: 28

${ }^{3}$ Sūrah al-'Ankabūt: 46
} 
Many wistful Āhādīth of the Kind Prophet SAW is very clear on this sensitive issue. The Holy Prophet SAW ensure the security of the nonMuslin citizen in a Muslim society likewise, "One who kills a man under covenant (i.e. a dhimmī) will not even smell the fragrance of Paradise".1 The historical peace charter of (Madīna (Methāq-e- Madīna) of the Wise Prophet SAW with Jews provides ever last security to the non-Muslim minorities in an Islamic state including freedom of religion in any case. According to the Historical collection of Dr. Muhammad Hamīdulah on (Methāq-e- Madīna);

"And the Jews of Ban $\hat{u}$ 'Aw'f shall be considered as one political community (Ummat) along with the believers-for the Jews their religion, and for the Muslims theirs, be one client or patron. He, however, who is guilty of oppression or breach of treaty, shall suffer the resultant trouble as also his family, but no one besides". ${ }^{2}$

Even the Quran takes a step furthers more and orders Muslims not to abuse the false Idols,

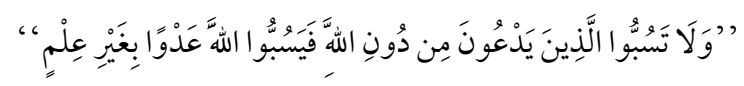

"And do not insult those they invoke other than Allah, lest they insult

Allah in enmity without knowledge".

These verses also make sure that Islam is a religion of peace and was not spread by force. So, this is an invalid question and biased attitude from the Orientalists that Islam has spread by force. The adequate response is given by the prominent Historian De Lacy O'Leary, "History makes it clear, however, that the legend of fanatical Muslims sweeping through the world and forcing Islam at the point of the sword upon conquered races is one of the most fantastically absurd myths that historians have ever repeated". ${ }^{4}$ Hence, these clear evidences show that Islam is a religion of peace and grants complete freedom of religion to non-believers. The Muslim role in many parts of the world is also an evidence of this fact that Islam does not force or compel anybody to embrace Islam.

\footnotetext{
${ }^{1}$ Sahī h Bukhārī , ḥ: 945

${ }^{2}$ Muhammad Hamīdullah, The first written constitution of the world, (Delhi: Nassir Books, 1996), Article:25, p. 59

${ }^{3}$ Sūrah al-An'ām: 108

${ }^{4}$ De Lacy O'Leary, Islam at the Cross Road, (London: AMS Press Inc., 1981), p: 8
} 


\section{Freedom of Association:}

Freedom of association is another significant part of the Islamic freedom of expression. Islam likes collectiveness or unity and appreciates collective activities rather than individual one. Therefore, The Nobel Quran gives freedom of association to a person for good purpose. The Quran grants this precious right and liberty as an objective. Almighty Allah, the lord of the universe expresses it likewise;

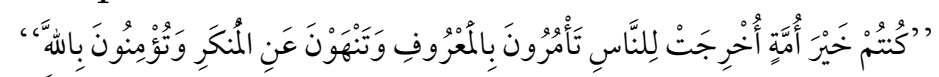

"You are the best of peoples, evolved for mankind, enjoining what is right, forbidding what is wrong, and believing in Allah". ${ }^{1}$

Syed Abūal a'lā Mawdūdī says in his exegetical note on the verse;

"This clearly indicates that if the entire Muslim nation collectively begins to neglect its obligation to invite people to goodness and forbid them from doing evil then it is absolutely essential that it should contain at least a group of people which may perform this obligation".

Freedom of association for peaceful purpose is an essential and integral part of human life. Therefore, Islam accepts this fundamental right for people's welfare and social development. Hence, Allah recommends it in the Holy Quran more likely;

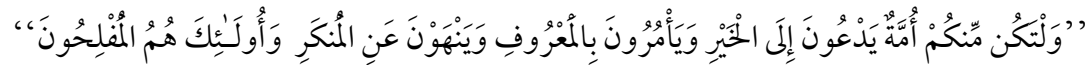

"Let there, arise out of you a band of people inviting to all that is good, enjoining what is right, and forbidding what is wrong: They are the ones to attain felicity". ${ }^{3}$

The Kind Prophet (SAW) also approved this very imperative right of a person in his wise hadith; "The hand of Allah is on the Community". Here, Muhammad Hāshim Kamālī comments seem most worthy, "The right to peaceful association naturally follows as an integral part of freedom of speech and expression. The Sharîa ah takes an affirmative stand on both of

\footnotetext{
${ }^{1}$ Sūrah Āle- 'Imrān: 110

${ }^{2}$ Mawdūdī, Human Rights in Islam, p: 30

${ }^{3}$ Sūrah Āle-'Imrān: 104

${ }^{4}$ Șaḥīh Bukhārī, ḥ: 14
} 
$\bar{I} Q \bar{A} N$ : Vol: 01, Issue: 02, Jun 2019

these rights and encourages association in purist of lawful objectives". ${ }^{1}$ Islam grants freedom of association all means according to his behavior and interest. Thus we can feel the Islamic interest in granting freedom of association for the spread of Islamic unity and Dawah and the establishment of the Islamic welfare state and a modest society. Therefore, Islam recommends every Muslim in all over the world to keep the Islamic community (association). It means Islam prefers and sometimes recommends adopting the Islamic association (to join Muslim community at all) in anywhere Muslim live and working in all over the world. In this sense Islam presents concept of globalization and universal society since fourteen hundreds years ago. A verse of Quran elaborates it more clearly;

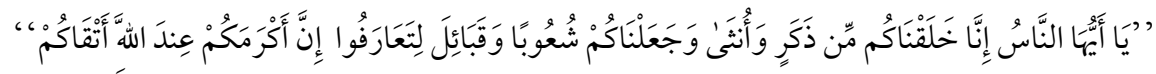

"O mankind! We created you from a single of a male and a female, and made you into nations and tribes, that ye may know each other (not that ye may despise (each other). Verily the most honored of you in the sight of Allah is the most righteous of you". ${ }^{2}$

Actually, Islam likes freedom of association and expression and most of the times link the both for peaceful objectives. Here a Muslim scholar kamāl Wāsfī speaks about freedom of association in Islamic context in a beautiful way; "Islam does not subscribe to any alliance other than unity in faith which is sufficient for Muslims. When a section of the Muslim Community enters into partisan alliance, it is bound to isolate others, and this would consequently lead to disunity". ${ }^{3}$ This statement clearly articulates that Islam appreciate the freedom of association of peaceful and positive objectives. Another Islamic scholar Hāmid Mowlānā relates it to the concept of communication. He clearly states that the concept of Ummah have deep relationship to the freedom of expression and communication. ;

"The concept of Ummah transcends national borders and political boundaries. Islamic community transcends the notion of the modern nation-state system: an Islamic community is a religio-economic concept and is only present when it is nourished and governed by Islam. The

\footnotetext{
${ }^{1}$ Kamālī, Freedom of Expression in Islam, p: 72

${ }^{2}$ Sūrah al-Hujurat: 13

${ }^{3}$ Kamālī, Muhammad Hāshim, Freedom of Association; the Islamic Perspective, IIUM Law Journal 3:1(1993), pp:23-36
} 
notion of community in Islam makes no sharp distinction between public and private; therefore, what is required of the community at large is likewise required of every individual member". ${ }^{1}$

The above discussion proves this fact that Islam grants freedom of association for positive and constructive purpose and also stops and prohibits it for an evil and destructive purpose. Commonly, it is a misconception or ignorance about Islamic teachings that Islam does allow any organization or association. According to researcher's humble opinion Islam prohibits only from political disorder resulting chaos and anarchy otherwise all positive movements and organizations are allowed and appreciated in Islamic state and society. Moreover, it is added on the behalf of discussion that Islam not only allow but most of the time recommended the collective affiliation to work better and safety of distortion.

\section{Freedom of Consultation:}

According to authentic Islamic teachings, freedom of consultation is another most significant individual and collective right and liberty. The Quran grants this essential human right for public welfare. The Prophet (SAW) used to consult his Companions in most of the matters. The Wise Quran illustrates the process of consultation on individual as well as public affairs for socio-religious advancement among the Prophet and his companions, "who consult among themselves (al-Shūrā 42:38)."It means according to Islamic teachings Consult issues to others weather they are individual or collective, this is mandatory from Almighty Allah. Islamic Sharī'ah highly focuses over it. In this Qurānic verse, Almighty Allah tells about the approaches and practice of the Prophet (SAW) and his companions that they consulted in all important collective and public matters. The Prophet (SAW) himself consulted the important matters with his companions. Haḍrat Abū Hurrīyyah narrates in a most famous Hadīth;

"I have not seen anyone to more diligent in consulting the companions then the Prophet (SAW) himself". ${ }^{2}$

\footnotetext{
${ }^{1}$ Hāmid Mowlānā, Theatrical perspective on Islam \& Communication, China Media ReSearch, 3:4 (2007),pp:23-33

${ }^{2}$ Tirmidhī, Muhammad bin 'Īsā, Jām 'al-Tirmidhī, (Riyadh: Darussalam, 2007), ḥ: 1714
} 
$\bar{I} Q \bar{A} N$ : Vol: 01, Issue: 02, Jun 2019

This Hadith of the kind Prophet SAW narrates about the most beautiful habit of the prophet SAW that they consulted issues most of the times to his companion and sometimes we observe they consult his most important personal issues to his closer companions. This behavior shows the importance of consolation and freedom of consultation in Islam. In Islamic teachings the sphere of consultation is spread from individual to public. Hāshim Kamālī writes about consultation;

"Being one of the salient principles of the government as prescribed in the

Quran is Shürā requires head of state and government leaders to conduct community affairs through consultations with community members". ${ }^{1}$

Keeping in view, in golden Islamic history the caliphate era was the classical age of freedom of consultation, while the prophet's era SAW was the most important era to establish the basic principles of Islamic welfare state, but actually this state was got boom in the era of righteous caliphate. Mawlānā Hāmid Anșārī comments on the age of the Caliph Hadhrat 'Umar (RA) in this way; "The age of Hadrat 'Umar (RA) was the excellent age for freedom of expression and consultation. It is his approach to call people in Masjid of the Prophet SAW, when an important issue needed to be consulted. Every person could express his opinion freely, in front of the caliph. He incorporated the spirit of common consultation in the Islamic government" 2 The institution of consultation in Islam is the oldest one and Islam recommends consultation to each and every one, even the prophet SAW also arrange the quality consultation in his blessed time period. According to a leading Islamic scholar Imam Ibne Taimīyyah's view;

"Allah commanded the Prophet SAW to consult the companion; despite he was the beneficiary of the divine revelation. The Qurānic command is not more concerned about the later Muslim generation, who would have no longer the Prophet among them, nor could they have had a straight contact with the divine revelation. ${ }^{\prime 3}$

This is also a fact and principle during consultation every one defend his own point of view and reject other's one but here Islam draw a

\footnotetext{
${ }^{1}$ Kamālī, Freedom of Expression in Islam, p: 41

${ }^{2}$ Anșārī, Mawlānā Hāāmid, Islam ka Nizāam-e-Hukūmat, (Lahore: al-Faisal Publishers), p: 112

${ }^{3}$ Ibn Taymīyyah, Taqī al-Dīn, Al-Sìyāsah al-Sharī'ah, (Cairo: Dār al-Kitāb al-'Arbī, 1951), p: 169
} 
boundary and provides guidelines that everyone has a right to consult and discuss but the exertive of the state or organization has a right to choose any one of the opinion or merge many of them. In Prophet's SAW Era we find many examples of it and even Quran point out this important aspect of the process of consultation. The Nobel Quran guides the Holy Prophet SAW very openly during process of consultation. This verse of the Quran one side recommends consultation on other side binds it with self-decision.

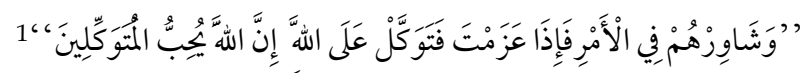

"And make counsel with them in the affair; so when you have decided, then place your trust in Allah; surely Allah loves those who trust".

An Islamic scholar J'afar Subhani interprets this verse of the Quran in the subsequent context;

"In the consultation sessions, it is common to express differing views.

Each person tries to defend his own ideas and to condemn those of others.

There must be a strong manager present who could gather all views and adopt the best view, or else such sessions would be fruitless". ${ }^{2}$

This and many other evidences show the concept and practice of freedom of consultation in the Islamic state and society remained peculiar from its very beginning. It is also stated that Islam opens the door of quality consultation from individual to state and family to society equally. For that purpose Islam binds the leaders of community and guardians of the family that they arrange quality consultation in the spheres to remove conflict and establish stability and peace.

\section{Freedom of Writing:}

It is historically proven fact that Islam awards right for a person to write and read freely. Islam considers it as an important part of freedom of expression in Prophet's reign and in the Modern era as well, because this is an age of information, writing and publishing due to globalization. We find the first revelation of the Quran is related to this right. It means Islam give importance to freedom of writings because the first revelation begins here.

\footnotetext{
${ }^{1}$ Sūrah Āle-'Imrān: 159

${ }^{2}$ Jaa'far Subhānī, Leading the Ummah, (Iran: ABWA Publishers, 1415AH), p: 35
} 
$\bar{I} Q \bar{A} N$ : Vol: 01, Issue: 02, Jun 2019

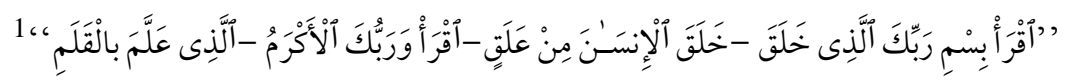

"Proclaim! In the name of thy Lord and Cherisher, Who created-Created man, out of a (mere) clot of congealed blood: Proclaim! And thy Lord is Most Bountiful, - He Who taught the pen".

The Kind Prophet Hazrat Muhammad SAW strategy on the occasion of the historical and decisive battle of Badar between Muslims and polytheists of Makkah for prisoners also show the Islamic interest to promote knowledge and skill of reading and writings. A number of Ahādīth and Seerah books describe this important story in different styles. A renowned contemporary Islamic Seerah writer Sheikh Safi ur Rehman Mubarak Puri stated the kind Prophet SAW decision about the prisoners of the battle of (Ghazwa) Badar likewise;

"Another form of ransom assumed an educational dimension; most of the

Makkans, unlike the Madinians, were literate and so each prisoner who could not afford the ransom was entrusted with ten children to teach them the art of writing and reading. Once the child had been proficient enough, the instructor would be set free."

According to the researcher's analysis, there is no single example on the word before or after that the prisoners of war were freed on the ransom of education. This example was only established by the kind and beloved Prophet Muhammad SAW. Hence, we are eager to say that Muhammad SAW has no parallel in the universe because He is model of excellence from Allah for whole human kind till the Day of Judgment.

Islam grants every form of rights and liberties in its own way and format, but some people try to explore it in the light of Western thought which is not a right approach. A well-known Muslim scholar Prof. Dr. Shafīque Alī Khan writes, "The Islamic concept of thought cannot and should not be studied in the light of Western ideas both the old and new. Islam being a unique ideology has its own standards of excellence truth and efficiency, right and wrong". ${ }^{3}$ This important comment illustrates the

\footnotetext{
${ }^{1}$ Sūrah al-'Alaq: 1-5

${ }^{2}$ Mubarak Puri, Safi ur Rehmān, The Sealed Nectar, (al-Rahīq-al-Makhtūm (English) (Lahore: Darussalam, 2006), p: 324

${ }^{3}$ Khan, Shafique, Freedom of thought and Islam, (Karachi; Royal Publishing, 1989), p: 35
} 
significance of Islamic concept of freedom of thought, writing and speech. It is also perceived that Islamic thought is a free and open minded thought and has its own criteria to differentiate between wright and wrong. Although Islam appreciate valid arguments but does not blindly follow everything of any thought and civilization in any issue.

Islam has the richest history of freedom of writing, speaking and intellectual liberty. Dr. Fathī Muhammad Osmān writes;

"The rights of free expression and free information cannot be separated from rights to think and believe (thought). Intellectual and linguistic capabilities characterize human beings, and thus, the right to form and express opinions represents an essential manifestation of human merits and of God's gifts". ${ }^{1}$

The above discussion opens the conversation that Islam is the first in history who publicly grants the right of writing and readings. Before Islam readings and writing were limited to the kings, religious leaders and philosophers. The public was an access to the writings, but with the arrival of the Prophet SAW this right reaches in the access of ordinary people. So we see that not any single companion of the Prophet SAW was illiterate, even a common and layman.

\section{Freedom of Discussion:}

Discussion is a most necessary and unique right of an individual and society. You do not stop any person from the discussion because Allah gives human being tongue to overstate and discuss the issues. Accordingly, Islam fulfills this most imperative requirement of a person and gives right of freedom of discussion to every person with some logical conditions and limitations. Here, Allah commands to the Prophet SAW;

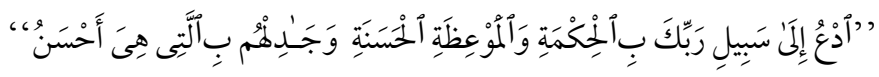

"Invite to the Way of thy Lord with wisdom and beautiful preaching, and argue with them in ways that are best and most gracious". 2

Not only in preaching and but also in routine matter Islam recommends fair speaking in every conversation. Allah states in the Quran

\footnotetext{
${ }^{1}$ www.usc.edu/schools/college/crcc/private/FreedomOfExpression/, (Accessed 18 Feb,2019)

${ }^{2}$ Sūrah al-Nahli: 125
} 
$\bar{I} Q \bar{A} N$ : Vol: 01, Issue: 02, Jun 2019

on another place about fair speaking in this way;

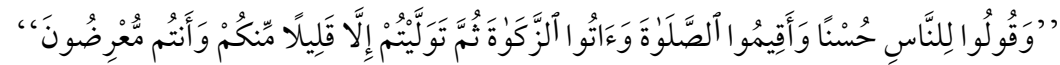

"Speak fair to the people, be steadfast in prayer, and practice regular charity. Then did ye turn back, except a few among you". ${ }^{1}$

The Prophet of Islam, Muhammad SAW said about fair speaking as; whoever believes in Allah and the Day of Judgment let him say good words or otherwise keep silent.". ${ }^{2} \mathrm{~A}$ renowned Muslim scholar said about this significant human right, "According to Islam, for freedom of speech, it is necessary to adopt justice and the right way which should consist of wisdom and consultation, otherwise it will be harmful to the society and the human being". ${ }^{3}$ Here, Professor Alagi Yorro opinion is considered to be thought provoking for freedom lovers. He rightly pronounced about Islamic freedom of expression likely to share;

"Freedom of speech and expression is recognized in Islamic legal theory and is a component of its incredibly high ethical footings. The objective of speech, according to Islamic philosophy is to build up love, tolerance, social harmony, and among members in order to ensure a peaceful coexistence". ${ }^{4}$

Keeping in view, Islam believes on quality discussion and lay down some important principles for that purpose. One of the most vital principle of them is any one may discuss a matter with negligence or lack of evidence but any person does not allowed to illuminate or hide the evidence at any cost. The Nobel Book of Almighty Allah leads us towards this important principle of discussion. Allah pronounces out in the Quran;

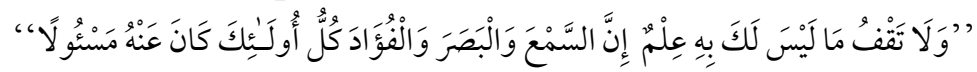

"And follow not that of which thou hast no knowledge. Surely the hearing and sight and the heart, all of these will be asked about it". ${ }^{5}$

Sheikh Muhammad Jawōd Chirrī supports this verse of the Quran from his valuable comments on this role. He frequently specified about this

\footnotetext{
${ }^{1}$ Sūrah al-Baqarah: 83

${ }^{2}$ Șahịị Muslim, ḥ: 4610

${ }^{3}$ Mawdûdī, Islam and Human Rights, p: 97

${ }^{4}$ Alagi Yorro Jallow, "Freedom of Expression and Human Rights in Islamic Perspective", Social Sciences Research Network, USA (August, 2015), PP.1-8; https://www ssrsn.com/abstract=2644727.

${ }^{5}$ Surah Al-Isrā: 36
} 
beautiful principle of Islamic discussion and communication likewise; "Islam never condemns an individual when he does not believe in a principle because of lack of evidence; on the contrary, Islam blames a person when he follows a principle while groping in the dark without illuminating evidence, or when such a principle is not in accordance with the truth". ${ }^{1}$

In the light of above fruitful discussion, it is obvious that Islam, undoubtedly, grants freedom of expression, but enclose it within some boundaries. Islam only bounds a person to speak for welfare and goodness. In other words Islam appreciates the valuable discussion, but discourages cheap, vulgar and hyped discussion. In some word it can be said it is the fundamental principle of Islam, when you speck good and think because this is the unique gift of God. In other words we can understand that Islam focuses on quality discussion and expression rather than discussion for discussion or expression. Definitely quality discussion opens the door of valuable conversation and knowledge and cheap discussion opens the door of distortion and chaos.

\section{Freedom of Knowledge and information:}

Freedom of information and knowledge (dissemination of information) is also another significant field of Islamic freedom of expression. Islam likewise grants freedom of knowledge and information to everyone for social and religious betterment. Islam awards freedom of information with some conditions. The unlimited or unrestricted freedom of information and discussion is not appreciable in Islamic teachings. Thus, a well-known Muslim scholar Prof. Dr. 'Abdul Haiyy Madanī writes about freedom of expression and information more prospectively; "In Islam, freedom of expression and information is a basic human right. Islam condemns spreading lies and false stories as well as passiveness and reluctance when the truth should be spoken and be highlighted". ${ }^{2}$ Many places in the Holy Quran Almighty Allah commands to believers for seeking of truth, "Confound not truth with falsehood, nor knowingly conceal the

1Chirrī, Muhammad Jawād, Inquires about Islam, (USA: The Islamic Center of America, 1986), p: 6

${ }^{2}$ Madanī, 'Abdul Ḥaiyy, "Freedom and Its Concept in Islam, Conference on Humanities", Historical and Social Sciences 17 (2011), PP: 116-121; www.ipedr.com/vol17/21-

CHHSS\%202011-H10000. 
$\bar{I} Q \bar{A} N$ : Vol: 01, Issue: 02, Jun 2019

truth (Al-Baqarah 2:42)". This is clearly meant that Islam allows any kind of knowledge and quires to search and support the truth. Otherwise the information can be fake or wrong which is not preferences of Islamic freedom of knowledge and information.

According to the Islamic scholars, this verse is a strong argument to seek authentic information from everywhere. So this verse is a clear evidence of freedom of information and knowledge in Islam. A leading Islamic scholar, Imam Rāzī comments interprets;

"This verse represents the rational need for the ignorant to refer to the knowledgeable. Since the people of the Abrahämic faith was educated in answering questions regarding the existence of the messengers and the Prophets before the Prophet (SAW), God has commanded the polytheists, who are doubtful on this issue, and refer to people of book for their knowledge". ${ }^{1}$

It is also a significant role of Islamic freedom of knowledge and information that Islam recommends an important sanction over that if an individual receive some important information, he does not share before authenticity or discussion with the authorities of related to this matter. The Honored Quran describes it as an important Islamic principle of getting knowledge and spread information. Therefore, the Holy Quran, the Book of Allah speaks;

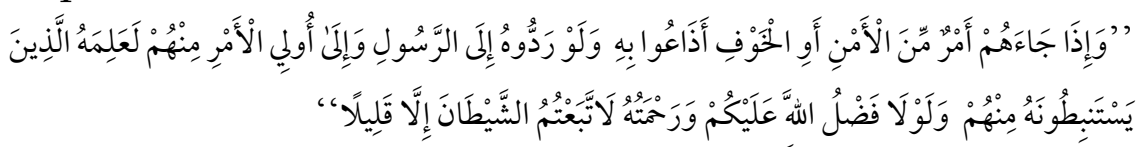

"And when there comes to them information about security or fear, they spread it around. But if they had referred it back to the Messenger or to those of authority among them, then the ones who [can] draw correct conclusions from it would have known about it. And if not for the favor of Allah upon you and His mercy, you would have followed Satan, except for a few". ${ }^{2}$

As it is mentioned before that the first revelation to the Prophet (SAW) in the cave of Hirā also states the necessity of knowledge and information in Islam. The Prophet Muhammad (SAW) also recommended the seeking of knowledge compulsory for every Muslim men and women.

\footnotetext{
${ }^{1}$ Rāzī, Fakhar bin Umar, Mafātih al-Ghayb, (Cairo: Dār al-Ghadh Arbī ,1991),7:112

${ }^{2}$ Surah al-Nisā: 83
} 
According to a Hadìth, to get knowledge is an obligation:

"Seeking of knowledge is an obligation on every Muslim". ${ }^{1}$

It's clearly means Islam permits the right of knowledge for everyone but with this consideration that it must not be a purposeless knowledge and may not be used to harm other.

\section{Freedom of Criticism:}

In Islamic religious context, right to criticize for positive and constructive purpose is a basic right and duty of a Muslim believer. Islam binds this important right with some objectives and limits because without proper limitations this right may harm others. The Respected Quran expresses it in many verses;

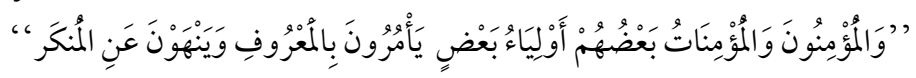

"The Believers, men and women, are protectors one of another: they enjoin what is just and forbid what is evil". ${ }^{2}$

Islam considers freedom of criticism a great responsibility. The Prophet (SAW) gives fundamental right to a Muslim to speak against government's bad activities or political weaknesses. The Prophet (SAW) declares it a great jihad; "The best form of Jihad is to speak a word of truth to a tyrannical ruler". ${ }^{3}$ In this context, the rightly guided caliphs of Islam were not spared. Mawlānā Shiblī Nu'mānī in his famous book, al-Fārūq writes, "Once a person said to 'Umar many times during most important public sermon, "O' 'Umar, be afraid of Allah". A person amongst the audience tried to stop that person. Hadhrat 'Umar said, "No, let him say. If these people will not say anything to me then what is the use of them". ${ }^{4} \mathrm{~A}$ research article presents a tribute to the Caliph Hadhrat 'Umar in this way, "Hadhrat Umar had given such type of the general freedom of criticism and expression to the people through his actions and orders that a common person did not hesitate to criticize or object on the Khalifah himself". ${ }^{5}$ In

${ }^{1} I b n$ Mājjah, Muhammad bin Yazīd, Sunan Ibn Mājjah, (Riyadh: Darussalam, 2008), ḥ: 2687

${ }^{2}$ Sūrah al-Tawbah: 71

${ }^{3} A b \bar{u}$ Dāwūd, Suleiman bin al-Ash'ath, Sunnan Abū Dāwūd, (Riyadh: Darussalam, 2008) ḥ: 4334

${ }^{4} \mathrm{Nu}$ 'mānī, Mawlānā Shiblī, Al-Fārūq, (Karachi: Dār al-Ishā'at, 1991), pp: 331-323.

${ }^{5}$ http://www.siasat.pk/forum/showthread.php?71894-Caliph-Al-farooq (Accessed 7 May, 2014) 
$\bar{I} Q \bar{A} N$ : Vol: 01, Issue: 02, Jun 2019

further proceedings it can be assumed Islam permits freedom of criticism but take some measures to regulate it for construction of the state and society. Doubtlessly, criticism is a most vital right and freedom but if we leave it opens it brings chaos and anarchism in the society rather than a positive feedback and accountability. Wahīdudīn Khan rightly observes;

"Criticism is not dire; rather it is a means for intellectual development. Without criticism, intellectual advancement is not possible. The choice before us is not one between criticism and the lack of it, but, rather between criticism and intellectual stagnation. If criticism is stopped intellectual progress shall cease". ${ }^{1}$

Here, it is again said Islamic ethics of criticism that it mentis some important principles about criticism and one foremost principles of Islamic criticism it will be positive and for constructive purpose, not criticisms for criticism or for destructive objectives. These are some key areas of the right to freedom of expression and speech in the light of Islamic teachings. The wise Quran not only gives freedom of expression, but it also encourages the people for freedom of expression to explore and search the truth. The Quran does not describe the detail of anything but it provides some important principles and basic law. Hadith of the Prophet (SAW) explain the matters which are described in the Quran because it is an essential duty of Prophet.

\section{Conclusion:}

It is perceived from the above discussion that in Islamic context freedom of expression is most important right and responsibility. Islam gives all kind of rights and liberties. However, Islamic teachings mention some rules and regulations for freedom of expression and criticism. The Criticism for the sake of criticism is also not good, but criticism for constrictive and positive objectives is appreciable. One thing which seems likely to clarify that some scholars frequently say or raise some questions that in Islamic teachings these issues are not clearly, but researcher stance is that every era has its own specific phrase and language, that's reason Islam discusses all those issues which are the basic need of humanity. As all of us know very well, this term is newly invented, but the basic idea is found in the Islamic history hundreds years before. For example, the basic

\footnotetext{
${ }^{1}$ Khan, Maowlāna Waḥīduddīn, Dīn-o-Sharī'at, (New Delhi: Good word Books, 2003), p: 231
} 
theme of this dissuasion or term is that is freedom, its need and requirement for humanity. It is frequently seen and read in primary sources of Islam that the word Hurriya which is exactly similar to freedom. In any case Islam spread and likes freedom and dislikes or stops slavery. It is also perceived these areas and key terms are similar to the Western freedom of expression but the details and interpretations of the term are entirely different from the Western thought.

(C) This work is licensed under a
Creative Commons Attribution 4.0 International Licence.

